\title{
LANDFILL PROBLEMS IN VILNIUS CITY
}

\author{
Violeta Ivinskiene \\ Antanas Mikalauskas \\ Grita Ambraziejute \\ Vilnius City Municipality \\ Alvydas Caplikas
}

Vilnius Special Autotransport company

Lithuania

\begin{abstract}
Vilnius City has two sanitary landfills, which are on operation now, one is Kariotiskes household waste landfill, started at 1987, second is demolition and construction waste landfill, ready to be closed.

There are four closed and recultivated household waste landfills in Vilnius city and close to it. The main problems of closed landfils are the same as of working one - biogas leakage almost in all of them, what is not environmentally safe; another problem is leachate production, which is especially increasing in autumn and spring seasons in Kariotiskes and still is a problem in two closed landfills.

Collection of recycleable materials was started at sources in 1994. Four fractions are collected : paper, glass, plastic and metal. In 1997 two special sites for collection of bulky waste were opened. Sorting of various recycleable materials at the landfill was started in 1992.The premises were built for sorting, packing and storage of saved materials. Paper, plastic metal, glass, wood, bricks etc. are collected there.

The first row of Kariotiskes landfill - 10,5 ha area , has reached 25-30 m high hill. It was closed in 1996. The recultivation project is on competition now.We are looking for a new site, which could serve for sorting, crushing and reusing of demolition waste.The problem is iron - concrete.
\end{abstract}




\section{KARIOTISKES HOUSEHOLD WASTE LANDFILL.}

Landfilling is one of the oldest means, which is traditionally used in Lithuania as solid waste management method. According to preliminary investigations, there are more than 800 closed legal landfills in Lithuania, which are recultivated or sometimes used for another purpose, such as a site for repairing and maintainance of containers, etc.

As the most part of the landfills in all Lithuania, so all the landfills, which belong to Vilnius City municipality, where installed and operated, paying no attention to environmental requirements. The law of waste is still not approved, though many corrections have been already made. The republican rules for operation of the landfills have been established in 1996. The first rules for operation, survey and maintainance of Vilnius City household waste landfill were established in 1992, and this year we prepared a new variant, which have passed the first reading.

The problems of two working landfills - for household and demolition waste are solved in Vilnius Municipality, City Economy department and both Environmental Protection department. The first one is solving more projecting and implementing of industrial works on the landfills, another one - monitoring and other environmental problems.

\section{Kariotiskes landfill waste composition and amounts}

The legal landfill, which was opened in 1987 as a household waste landfill, is situated in Trakai region, $27 \mathrm{~km}$ from the centre of Vilnius City and has the name of Kariotiskes. It is used for waste removal by Vilnius Municipality and all Trakai district - six municipalities - Trakai, Grigiskes, Vievis, Elektrenai, Rudiskes and Lentvaris towns. It covers about 578,8 thousand habitants and about 55,9 thousand in those six city municipalities,(data from 1997.09.10. in Statistic department). In reality, some industrial waste from factories and commercial waste is deponied here too. We are inclosing a list of various types of waste, which is deponied in Kariotiskes landfill

- household waste, collected from habitants,

- food waste, paper waste from offices, institutes, schools,children gardens,

- industrial waste from enterprises, institutes and offices,

- plastic systems and food waste from hospitals and policlinics,

- some part of demolition waste and greenery from parks and streets

- commercial waste from shops, restaurants, street little shops, etc.

Due to the data of joint-stock company Vilnius Special Autotransport, which is operating the landfill, every year they dump there more than 900.000 kubic metres of waste.Waste was not waged till this year and was not precisely registered till 1992, when the first regulation rules were adopted. Now they are able to wage only industrial waste, but are working on the project of computerizing the wages. It will help to work quiker and to know real data about waste. And of course to make better control of waste composition, quantities and companies - 
waste owners. Though the first landfill regulation rules declared the lists of waste, permited and forbidden to landfill, still the enterprises try to dump there everything, they want. So the control in the landfill should be more strict and experienced. Much of organic waste, industrial waste and sometimes environmentally dangerous things should not be dumped there.

For these reasons the landfill is fulfilling rapidly and in a very short time we should think about construction and arrangement of a new landfill. It is supposed to use a site, laying nearby, after it is used for recultivation of the first row of the landfill. It is very difficult to find a new place. This site has a good clay for recultivation.

So, at present time we are facing problems of minimizing the amounts of deponied waste. This task is achieved by:

sorting, separation of materials at sources, collection in bulky waste sites, enterprises and preparation of new rules for landfill regulation, including above mentioned things.

\section{Collection of recyclable materials, sorting and separation}

Collection of recyclable materials at sources was organised in 1994, initiated by Copenhagen Environmental Agency. Now there are more than 1000 containers almost in all city districts, much more in sleeping regions, than in the centre, where is little space to put them.

There are four types of collected materials : plastic, metal, paper and glass. Containers are the same type but different colour and holes for putting in the materials. The habitants were informed how to sort their waste, how to collect recyclable materials at home. We prepared a special advertisement paper, talked on the radio and showed a short information on various TV programs. First year we began from 45 containers in two districts and finished with 500 containers in 12 districts in half a year. The job was organised by municipality and special private company SITIS, which is making street cleaning and waste collection from $20 \%$ of habitants.

First experiments had showed, that all, which was collected, must be sorted once more. So the workshop was organised, where two workers had to sort collected materials by hands. During last years two other companies started collection of recycleable materials. Now were are many little companies, collecting paper and metal, but very few collecting glass and plastic, because it is difficult to realise. We have 2 paper mills near Vilnius city, plastic treatment factory and 2 glass recycling enterprises in Kaunas and Panevezys, which are dealing very slowly now. Besides this in 1997 there were opened two sites for collection of bulky waste. They were organised after nine specialists from Lithuania have learned in Sweden, in Waste management training courses. Both sites are situated in different parts of the town. The citizens are bringing here old TV sets, sewing and washing mashines, computers, plastic and metal bulky waste, demolition waste, glass, old 
accumulators. There are private companies, which gather from habitants old accumulators, galvanic batteries, mercury lamps, old tyres, so on.

The special workshop for contamination of mercury lamps will start its work this autumn. Private company Vienituras is finishing construction works of plastic PET and tetrapak recycling enterprise. They have opened the first reloading and resorting station in Vilnius City recently. The first line is for resorting of recycleable materials. The second one - for sorting of household waste.

\section{Waste composition}

\section{Household waste}

Household waste from habitants usually is colected in containers. We have made a little experiment together with magistrants ecologists, checking the composition of containers, from individual sector, both from living houses. The preliminary investigations had showed, that it is formed from:

- $46,6 \%$ of organic waste, formed from kitchen waste, food waste remains, garden compostable waste from individual houses and vegetable - flowers markets, but only $10 \%$ comes from individual sector, who can compost part of organic waste;

- $6,78 \%$ of plastic waste, mostly polyethene bottles and packages from lemonade, juice, petrol, shampoons, washing means and once - used plastic bags, plates, plastic glasses, polyethene from green houses;

- $4,18 \%$ metal scrap,- tins from beer and juice, bicycle details, kitchen pots;

- $10,17 \%$ of glass breakage and non changable used bottles;

- 13,4\% paper and cardboard ( waste paper ), mostly polluted and nonrecyclable,

- $1,48 \%$ tetrapak from milk and juice production;

- $1,7 \%$ construction waste - flat repairing waste - ceramic tiles from kitchen or bathroom, concrete slab chips, broken kitchen utensils, constructions from old houses, brickbats;

- $3,19 \%$ wood wastee, - old fumiture, and chips;

- $2,45 \%$ old drugs or galvanic elements, details from cars, polluted with oil, electronic waste;

- $5,4 \%$ textile ( sinthetic and natural rags);

- $1,92 \%$ sinthetic or natural leather , rubber products (old boots, bags,etc.);

- 2,5\% of sand, soil and sweepings 9 in this case this part from individual sector was different and especially big $41,8 \%$ of very dump mass.

\section{Industrial waste}

Industrial waste which is allowed to dump is coming from enterprises. The special landfill regulation rules for Kariotiskes areused from 1992. They are to be changed and stricted in 1998.There is allowed to depony such industrial waste products, which are not hazardous, and which have no recycling solution till now. 


\section{Leachate problem}

The contents of landfill waste is very dump. First it has much organics and degradation takesplace in it. We suspect its natural moisture is about $30 \%$. Second, it is due to precipitation - rain and snow, because it is not well covered and not recultivated yet. Besides that, often waste is collected and carried in non hermetically closed contamers, so that when it is raining or snowing during two or three days, and if the contamer is standing not in the special premise, but in the yard or on the street, so of cource, it is full of water, and the moisture of waste can reach $80 \%$.

During landfilling, as usual, waste is daily covered with sand or soil, not less than $10-20 \mathrm{~cm}$ and compacted in relation 1:3. For this purpose the Soviet tractor "Kiroviec" with specially changed wheels is used.

Now the second row, which was started to operate last year, had reached 6 - 9 metres from the bed bottom. All water, which is coming by rain and snow, is absorbed by dumped wastea because the Ist row of the closed part of the landfill is not covered by clay or other protective layers and is not recultivated with special plants.

The drainage system was constructed not very clever, so that sometimes waste blocks the pipes and then the leachate level is rising and threatening to go out of the landfill to environment. During exploatation of the first row (in 7-9 years ) two leachate ponds had formed in a forest round the landfill, and some part of leachate of course had went to a pond, where galvanic sludge was collected for 34 years from the beginning of the dumping here. It was soluted and dispersed by leachate and landfilled together with waste, so that now this pond is full of rain water, mixed with leachate. Leachate gathers in spontaneous pools in the lowest places of the second landfill row.

The project for recultivation of the first row now is layed on competition. It will have place on 30 of September, 1997. Many companies are ready to take part in it. The question is which of them is able to work out the development of the project. This project has only a scheme for location of biogas borings and ditch or gutter around the landfill. No gas extraction, utilisation or leachate treatment is foreseen in it.

\section{Biogas in the landfills}

Explosion accident, which had happened in 1995, in the lowest place of the landfill, had showed that biogas is one of the landfill problems to be solved. Succsessfully, nobody was killed, but the premises were destructed. During operation of the $1^{\text {st }}$ row, workers and scavengrs used to warm themselves by biogas, fired in two or three places of the landfill.

As mentioned above, the recultivation project doesn't foresee biogas extraction process. According to this, the special biogas composition investigations and pilot pumpings will take place in October, organised by Lithuanian geologists group and German experts. The same investigations are started by Baltconsult company together with Danish experts on closed Fabijoniskes landfill. It is very near from living houses - only $100 \mathrm{~m}$ and can be dangerous. 
In the end of this year, the competition will be announced for biogas extraction and leachate collection in Kariotiskes landfill. It is supposed, that companies will go in the consorcium, because much experience and financation is needed for implementation of such projects.

\section{Scavengers}

Habitants from villages around Kariotiskes landfill or poor asocial people from Vilnius City are used to come to the landfill. As were is many recycleable materials, they are collecting paper, bottles, bricks, plastic, wood chips, textile, metal and food remains. They are collecting food for their animals and birds, selling resorted and separated materials to Vilnius special Autotransport company.

\section{The tasks, which we put as of first importance, are:}

1. 1 row of the landfill was closed in 1996 and covered with small amount of sand. Gas extraction and utilisation project is needed. The nearest town is -12 $\mathrm{km}$ away, Vilnius City is $27 \mathrm{~km}$ away. Leachate leakage and treatment must be solved.

2. 2 row was opened in 1996.01. Leachate in spring and autumn appears on it. Little sorting , big amount of organic waste, industrial waste is deponied too, hazardous - no. Bad compacting. Many scavengers. Tasks: to lay down the drainage and gas collection pipes, in connection with 1 st row.To increase sorting, collection of recyclable materials and composting in the town.We had prepared a new variant of more strict regulation rules for operation of the landfill.

3. 3 row - to be opened in future - must be designed and constructed in a modern way. Maybe with biocells.

\section{Difficulties:}

- We must think about foreign financation or loan, because we get unadequte money from budget and environmental protection fond.

- The earth is in Trakai city region.

- The project of recultivation of the 1 st row doesn't solve gas and leachate problems.All the basic problems of three rows must be solved together.

\section{Landfill for construction and demolition waste}

The landfill was opened in 1991. It is situated in Dvarcionys near Ceramics ans bricks producing enterprise. It has only 1,5 ha area. Construction and demolition waste was deponied here without any sorting. Only in 1994 they began to sort some of materials. This landfill is to be closed on days and we are looking for a site for construction and demolition waste recycling. The biggest problem is iron - concrete 